\title{
Perspectives of High-Achieving Women on Teaching
}

\author{
HELEN SNODGRASS \\ Stanford University, CA, USA
}

\begin{abstract}
High-achieving women are significantly less likely to enter the teaching profession than they were just 40 years ago. Why? While the social and economic reasons for this decline have been well documented in the literature, what is lacking is a discussion with high-achieving women, as they make their first career decisions, about their perceptions of teaching and what makes it more or less desirable than other professions. This study explored what they are looking for in a career, their views on teaching, and the sources that have influenced those beliefs with the goal of identifying approaches to reversing the current trend.
\end{abstract}

\section{INTRODUCTION}

Every year as summer comes to a close, new stories crop up about teacher shortages, leading parents to fret over whether there will be anyone standing at the front of their child's classroom on the first day of school. While shortages do sometimes exist and tend to be most severe in areas such as mathematics, science, and special education and in schools that serve low-income populations (Herszenhorn, 2006), these vacancies are almost always filled, and teacher to student ratios have even been decreasing in recent years.

Shortages, then, are not the main problem. The most pressing issue is not whether there will be enough teachers, but who those teachers will be. Teacher quality, as measured by scores on assessments of mathematics and verbal ability,

Address correspondence to Helen Snodgrass, 5353 Institute Lane, \#9, Houston, TX 77005, USA. E-mail: HelenLS@stanford.edu

@ Readers are free to copy, display, and distribute this article, as long as the work is

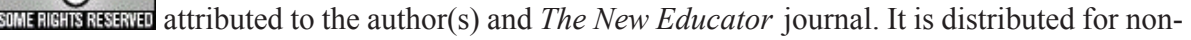
commercial purposes only, and no alteration or transformation is made in the work. More details of this Creative Commons license are available at http://creativecommons.org/licenses/by-nc-nd/3.0/. All other uses must be approved by the author(s) or The New Educator. The New Educator is published by the School of Education at The City College of New York. 
has been declining in the United States over the past 40 to 50 years. More teachers are being drawn from the lowest deciles of achievement and fewer from the highest (Corcoran, 2004). This trend is largely due to changes in the composition of female teachers, who have long comprised the majority of the teaching force and thus have had the largest impact on its overall makeup (Hoxby, 2004). Much of the research on changes in teacher quality thus focuses on women and the factors that have affected their entrance into the teaching profession.

While relative scores on mathematics and verbal tests certainly do not account for all aspects of teacher quality, higher teacher scores have been shown to correlate with higher student achievement (Rice, 2003). This relationship makes the decline in these measures within the teaching profession a pressing matter. Significantly, average teacher quality is not equal across different types of schools. Minority, poor and under-performing students, especially in urban areas, are the most likely to attend schools with lower quality teachers, with a negative impact on their achievement (Lankford et al., 2002; Boyd et al., 2007). In order to maintain highquality education and positive student outcomes, policy makers and educators will have to find ways to attract skilled applicants to teaching and to encourage them to stay once there.

Part of the decline in high-achieving teachers is due, ironically, to expanded opportunities for women and minorities. Until recently, teaching was one of the few acceptable occupations for women and one with a comparatively small gender pay gap. Therefore, it was to be expected that the majority of women entering the labor force would become teachers. The feminist movement and subsequent legislative changes, however, have drastically expanded the professional opportunities open to women. They are now able to participate in a much wider range of careers, and pay equality has significantly increased in most competing fields. The pull of new, interesting opportunities and higher salaries has drawn many potential candidates away from teaching to other professions (Hoxby, 2004). This growth in options for women would not have affected teacher quality if it impacted all candidates equally. It appears, however, that these changes have had the most influence on the prospects available to high-achieving women, rendering them the most likely to choose a different career or to leave teaching early in their careers.

The disappearance of high-achieving women from teaching and the economic and social reasons for it have already been well documented in both economic and educational literature (Corcoran, 2004; Murnane, 1991; Flyer \& Rosen, 1997; Temin, 2002; Hoxby, 2001). What seems to be lacking, however, is a discussion with high-achieving women, as they make their first career decisions about their perceptions of teaching and what makes it more or less desirable than other professions. While the socioeconomic factors mentioned above form part of the context within which these women will make career decisions, those decisions will be more directly based on their perceptions, needs, and desires. The intent of this study is to begin to fill this empirical gap by exploring the perceptions of 
high-achieving undergraduate women on teaching, what they are looking for in a career, and the sources that have influenced those beliefs with the goal of identifying approaches to reversing the current trend. This article particularly focuses on their view of teaching as a public service and how that affects their perception of and interest in teaching.

\section{METHODS}

\section{Surveys}

I conducted a mixed methods research study using both a survey and interviews of undergraduates at a large, highly selective research university on the West Coast, in the winter of 2008. The survey was distributed to students in 20 classes from 12 different departments. The one-page survey took about five minutes to complete, and participants were not compensated for their time. Participants were 386 undergraduates (yield $=91 \%$ ) from 45 different majors (divided into "humanities," "social sciences," and "science/technology") and included all four class years. Status as a student at this university was used as a proxy for high academic achievement based on the standards used for admission to the university. While females are the focus of this study, survey participants included both males and females in order to test whether there were any significant differences between the two genders. Participants were drawn from all four class years to understand how their thinking about occupations, and especially teaching, may change over their undergraduate career. The high response rate suggests that the respondents were a largely representative sample of the students in the classes surveyed. The survey explored students' interest in teaching as a career, what they found attractive about teaching, what they found more attractive about other careers they had considered, and what their perceptions were of teaching as a profession. For exact survey questions, see Appendix A.

\section{Interviews}

The interviews were begun after many of the surveys had been collected so the results could inform the interview questions and explore in greater depth these students' perceptions of teaching. The interviews were semi-structured and lasted 30 to 40 minutes, and interviewees were all compensated $\$ 20$ for their time. Interview participants were undergraduate females, all upperclassmen, who were chosen from a list of those who expressed an interest on the survey in being contacted to discuss their views further (see Table 1 for a list of participants, their majors, and their interest in teaching). Pseudonyms have been used in the discussion of the results to maintain participants' confidentiality. Students towards the end of 
Table 1. Interview participants' class year, major, and interest in teaching

\begin{tabular}{|c|c|c|c|}
\hline Name & $\begin{array}{l}\text { Class } \\
\text { year }\end{array}$ & Major & $\begin{array}{c}\text { Have you } \\
\text { considered teaching? }\end{array}$ \\
\hline Anna & Senior & English & Yes, short-term \\
\hline Jamie & Senior & American studies & Yes, short-term \\
\hline Karen & Sophomore & Art history & Yes, short-term \\
\hline Jess & Junior & Anthropological sciences & Yes, short-term \\
\hline Alex & Senior & Human biology & Yes, short-term \\
\hline Lindsay & Senior & Symbolic systems & Yes, short-term \\
\hline Maria & Senior & Communications & Yes, long-term \\
\hline Lisa & Senior & Urban studies & Yes, long-term \\
\hline Katie & Senior & History & Yes, long-term \\
\hline Eva & Senior & Symbolic systems & Yes, long-term \\
\hline Kayla & Junior & Psychology & Not seriously \\
\hline Sam & Senior & Biological sciences & Not seriously \\
\hline Liz & Junior & Psychology & Not seriously \\
\hline Mia & Junior & Biological sciences & No \\
\hline Laura & Junior & Psychology & No \\
\hline Nicole & Junior & English & No \\
\hline Rachel & Senior & Psychology & No \\
\hline Carmen & Senior & Product design & No \\
\hline Emily & Senior & Public policy & No \\
\hline Julia & Junior & English & No \\
\hline
\end{tabular}

their undergraduate careers were chosen because they were believed to be more likely than younger students to have thought seriously about careers. They were also chosen to achieve a balance of both those who have considered teaching and those who have not and of humanities, social science, and science/technology majors. There were three to four students in each of the six categories for a total of 20 interviews. This distribution allowed study of students in majors from which teachers are more frequently drawn as well as those from which they are less frequently drawn to understand how students' perception of teaching and their attraction to it may differ depending on individuals' field of study and alternative career opportunities. A list of interview questions can be found in Appendix B.

\section{Data Analysis}

After collecting the surveys, the data was entered in Excel and analyzed using STATA, a statistical software program. Means and percentages were used to generate descriptive data about the participants and their interest in teaching and other professions. 
The interviews were analyzed through a combination of open and structured coding. The interviews were initially read to generate a list of codes that was then organized, condensed, and applied to all of the data. The codes were organized into the two broad categories of what students believed was important in a career and their perceptions of teaching. Their perceptions of teaching were further broken down into their interest in teaching, what they found attractive or unattractive about teaching, and the sources that they believed influenced these views.

\section{RESULTS}

\section{Teaching as a Public Service and a Sacrifice}

One of the most surprising results was simply how many students had considered teaching. Of the survey participants, $57.8 \%$ have given at least some consideration to teaching (a ranking of 3 or higher on a scale of 1 [Never] to 5 [Seriously]). When asked to check all careers that one has considered, $44 \%$ checked teaching, making it the second most-considered career after medicine (46\%). Forty six percent of the students surveyed also said they had considered or were considering Teach for America (TFA) (33\%) or another Teaching Fellow program (13\%), while only 18\% had considered or were considering a graduate teacher education program (see Figure 1). Interest in TFA was relatively evenly divided across most levels of interest in teaching, even among those with little interest in teaching, whereas interest in teacher education programs was concentrated among those with higher levels of interest in teaching, suggesting that interest in teaching is not necessary for interest in TFA.

Participants were next asked what they found attractive about teaching, whether or not they were considering pursuing the career. The most frequently checked answer was "working with people" with $71 \%$, followed by "rendering a public service," checked by $55 \%$. This suggests that the perception of teaching as a public service is one of its main attractors.

Similarly, twelve of the interview participants, including both those interested in teaching and those not, described teaching as a public service, a profession that allows one to have a positive impact on people's lives. Some of these students tied the public service aspect of teaching specifically to working in a school in a lowincome area, whereas others saw teaching in any capacity as a service. Many of them found this aspect of teaching very attractive, especially when compared to some of the other professions they were considering. Maria, a senior planning on becoming a teacher after graduation, said that, with teaching, compared to the jobs in computer science and communication which she had considered, "It just seems like there would be more of a purpose everyday. It is something I feel is important." 


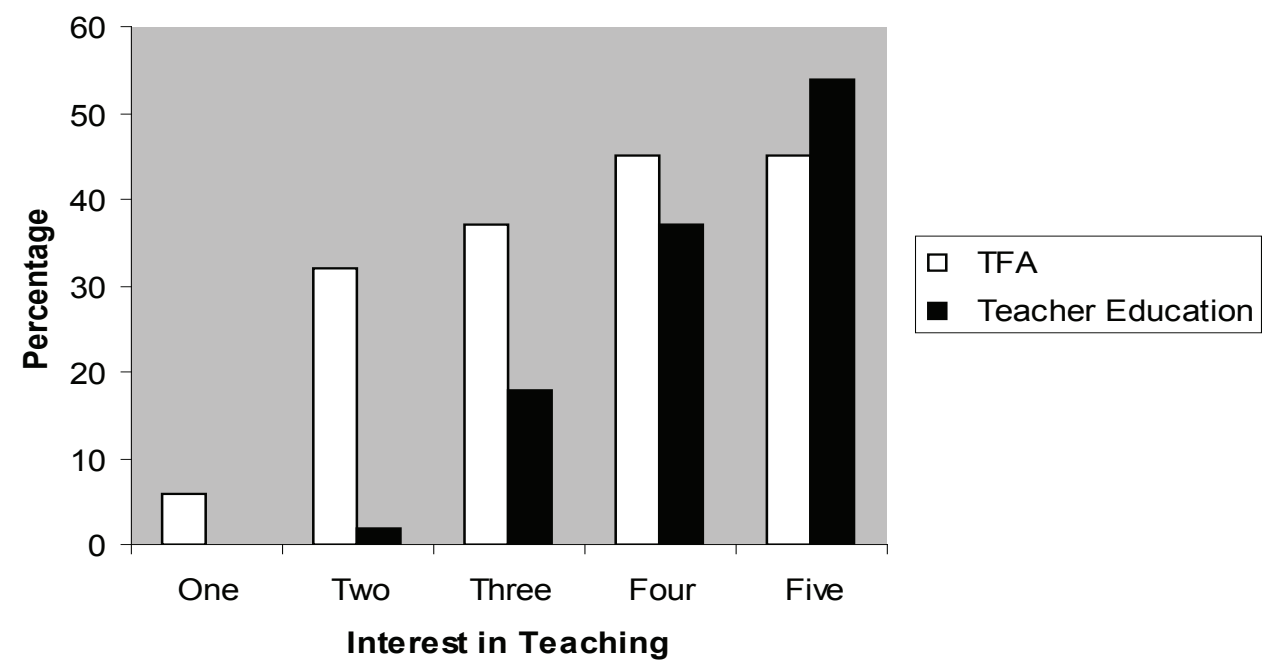

Note: Interest was measured on a scale from 1 (never considered teaching) to 5 (strongly considered teaching).

Figure 1. Interest in TFA and teacher education programs

Why, then, if many students have considered teaching and find its public service aspect attractive, do more of them not pursue teaching as a career? Among the ten interview participants who had expressed a strong interest in teaching, only four of them would ever consider it as a long-term career if they went into it. Although students may find public service an attractive feature of teaching, it does not seem to be as high on their list as other job features. When students were asked what characteristics they were looking for in a career overall, only six of the 20 students specifically mentioned wanting one that would involve some sort of public service.

Nor does it seem to be an attractive enough feature to compensate for the other aspects of teaching that led many students to consider it not just a public service, but a sacrifice, in which you were giving up something you wanted in order to help others. Students used the terms "altruistic," "noble," and "sacrifice" repeatedly to describe teaching, whereas they discussed other careers more frequently in terms of what the benefits would be for themselves. As Katie described her reasons for considering teaching, "I am doing it more for other people. It is more noble. I get something out of it, but it is a more humanitarian satisfaction. Whereas the other ones [other careers], I am interested in them because I think they'll be fun." Her interest in teaching partly stems from the impact she believes she could have as a teacher, but she feels that she would be giving up some of what she wants for the sake of other people. Liz stated, "You are making a difference in people's lives, but you are doing it at an expense to yourself." What participants saw as the "expenses" of teaching included forgoing a higher salary, a more prestigious job, and the opportunity to do something "more" in one's field. 


\section{Salary}

When asked what was most important to them in making career decisions, the second most frequently mentioned factor (after the individual's enjoyment of the job) was salary. While most said that they did not necessarily need a very large salary, they wanted to be sure they would make enough money to live comfortably, and 3 students were concerned about being able to support their family. Jess, who had considered teaching for a year or two before graduate school, said, "Obviously I need financial support. Everyone wants financial stability — people are practical, including me." As she indicated, the salary a job can offer is an important factor that most people consider in addition to the enjoyment they expect to receive from a job simply because, practically, they must. Emily tied the importance she placed on salary specifically to paying off her student loans, saying that she would have chosen a less expensive university if she had not expected to obtain a high-paying job.

Both the interview and survey participants agreed that teaching would not provide them with a high salary. Seventy percent of students surveyed said they found the salary and benefits of other jobs more attractive than those of teaching. Additionally, most students disagreed or strongly disagreed with the statement, "A teacher's salary is adequate given the work done" (mean $=4.05$ on a scale from 1 [strongly agree] to 5 [strongly disagree]). Except for one, all the interview participants felt that teachers are underpaid for their work.

Participants noted that this may have an impact on the ability of schools to attract high-quality teachers. They believed that this was especially an issue for students from their university, who not only have received a very expensive education, for which they may have to pay off loans, but also are able to obtain a job their first year out of college that pays significantly more than a first year teacher's salary. Some students noted that the relatively low salary turned them away from teaching, and almost all predicted that it would have that effect on others even if it did not matter to them personally. As Liz said, "It is not economically rational to be a teacher because we go to [university's name] and spend all this money on our education so that it will come back to us in our profession. Teaching is not going to get that money back." For some of the participants who were considering teaching, salary was one factor that made them favor teaching for a few years after college before moving on to another job that would give them the financial grounding they wanted long term, especially if they were planning on having a family.

\section{Status}

Only two students expressed a need for a job with a high prestige and social status. Despite the small number who explicitly discussed the importance of the status of a job, when asked about the status of teaching, both survey and interview participants 
said that it was a feature that detracted from the appeal of teaching. Thirty seven percent of surveyed students found the status of other professions more attractive than that of teaching. Though the participants themselves expressed a belief in the importance of education and an admiration for teachers, they contrasted these views with those of society.

Seventeen of the 20 participants argued that teaching was undervalued and not "taken seriously" as a profession. They cited a number of reasons why they believed society might not regard teaching as highly as they did, including: teaching is seen as an easy job with short hours and long vacations; it has traditionally been a femaledominated occupation; teachers are not seen as having the same training or professional knowledge as those with higher status jobs; it has a relatively low salary structure; teachers are often blamed for failing schools. Participants believed that all these assumptions about teaching lead to a societal view of teaching similar to that expressed by the old maxim "those who can do; those who can not teach." They felt this made the choice to go into teaching especially difficult for students at prestigious and expensive universities. Because these students are typically ones who "can," choosing teaching is seen as, in Alex's words, "such a waste if you have a [university's name] education. Why would you just be a school teacher?" Mia believed that "some people view teaching as a sacrifice in your career because you could do so much more." While they did not feel this way themselves, Alex, Mia, and the other students believed that choosing teaching as a career would be viewed by others as a waste of both their potential and of the expense of going to their university. Reflecting this dichotomy, when asked to rate their level of agreement with various statements about teaching on a scale of 1 ("strongly agree") to 5 ("strongly disagree"), most students strongly agreed or agreed (mean $=1.95$ ) that "teaching is a worthwhile career option for a [university's name] undergraduate. For the statement, "Teaching is a high-status profession," on the other hand, most students neither agreed nor disagreed (mean $=3.13$ ), though the responses were spread more evenly across all options.

While most students said that they themselves have respect for teachers and the teaching profession, the language they used to describe teaching suggests that they, to some extent, hold many of the same perceptions of teaching they saw in society. Participants frequently spoke of wanting to do "more" than simply teach or of using teaching as a way to gain experience before "moving up." Nicole said that her mother used to be a teacher but was now a consultant for school districts and that she could not see her mother now being "just" a teacher. This language implies a view of teaching as less than other professions - a place to start before doing something bigger and better. Sam, while saying that she believed teaching was important, also asserted that part of her desire to go into medicine and research was to have an impact on society that she did not see teachers having. She explained, "As a [university's name] undergraduate, you hear that you are the future leader of America. You are shaping the way society is. And a teacher...most teachers play a limited role in affecting society." 


\section{Difficulty of Teaching}

Not only did students believe teaching to be a lower-paid, lower-status job than others they were considering, but they believed it to be more difficult, increasing their perception of teaching as a sacrifice. Fourteen of the interview participants, including eight of those who were considering the profession, asserted that they believed teaching to be a very difficult job for a number of reasons. Seven students expressed concerns that teaching would be stressful and emotionally draining because they saw teachers as having a lot of responsibility for their students and becoming very involved with their outcomes. Lisa, Katie, and Alex specifically compared this aspect of teaching to the demands of other jobs they were considering, such as working for a non-profit or at another office job. Lisa explained that "Working for a non-profit seems somewhat less emotionally demanding. It seems more detached in a way." She said this type of work would be less "in the trenches" than teaching, which she saw as a job with a lot of responsibility for and involvement with the kids one teaches. For some, this worry made them question whether they should enter teaching or whether, if they did, they could remain in the profession for more than a few years.

In addition, students assumed that there are a number of factors that make teaching even more difficult than it may intrinsically be. Their views came from their own experiences in school, classes they had taken on education at their university, and parents or friends who had taught. The factors included a lack of resources, large class sizes, difficult students, and having to deal with the bureaucracy of a school and school system. Some of the participants noted that these issues might be especially problematic in a lower income public school, but they said that that was where they would prefer to teach, at least for the short term, because they would be able to have a greater impact. They saw insufficient access to resources or funding as something that would hinder their ability to teach well, to be creative in their lessons, and to give their students the best opportunity to succeed. Similarly, large class sizes and difficult students were seen as barriers to being able to reach out to each student and address their individual needs. As Kayla said, "Teaching in a large classroom can be really stressful. It would be frustrating not to be able to allocate sufficient time to everybody. I think people fall through the cracks just because there are not enough resources to deal with that." Students also believed that what they called the "bureaucracy" of teaching added to its difficulty. Eva had always been told by her mother, who was a teacher, "It is 10\% teaching, 90\% bureaucracy." Eva and other participants discussed having to deal with school administrators, attend staff meetings, administer standardized tests, and accept top-down policies with which one might not agree as taking away from the time they had to devote to teaching as well as limiting their options and creativity in planning lessons.

Their perceptions of all these barriers to being a successful teacher and enjoying one's work led many of the students interviewed to have a slightly cynical 
view of teaching. While they all believed in the importance of education and its potential to have a significant positive impact, they believed that the difficulties associated with teaching would make it hard to achieve this in reality. Jamie, whose mother has taught for 30 years, explained "I tend to be pretty cynical because I study it and I have seen my mom teaching. You can work there for 30 years and not see change in the community you are working in, and that is really depressing." The students with more knowledge of teaching, either from having a parent as a teacher or taking classes on issues in education, tended to be the most cynical. Lisa, who had some interest in teaching but felt like she needed to explore her options more, said, "I guess you should not be a teacher if you think you might want to be a teacher. It is really demanding and it is an important job. I would not want to put myself in a classroom of kids [if I were] not really sure that I wanted to be there."

\section{Effects of Perceptions on Interest in Teaching}

These students' perceptions of teaching as a relatively low-paying and lowstatus, but time and energy-intensive job, led them to think of it not simply as a public service, but as a sacrifice; one which most were not willing to make. Although half of the participants interviewed had a strong interest in teaching, and some of the others had at least considered it, only four were confident that it could be a long-term career if they chose it. As Lisa said, if "I really loved what I taught and where I was and was taken care of as far as benefits...then I could do it for a while," but seemed skeptical that all her criteria could be fulfilled.

The other six participants who were still considering teaching mainly envisioned it as something they might do for a few years, but not longer. Many of their reasons for only wanting to teach for a short term related to the notion of teaching as a sacrifice. Laura and Karen saw teaching as a way to make a difference for a few years and gain skills before moving on to something with more prestige and a higher salary. As Karen said, "I guess it is pretty well known that teachers do not get paid very well, so I think I would want to use it as more of an experiencebuilding technique - a stepping stone up into something else." While they felt that they would enjoy teaching, they did not see it as a desirable long-term career, as indicated by the wish to move "up". Alex and Jamie did not think that they would be able to sustain the energy and desire for teaching much longer than a few years, either because they saw the job as very draining or because they did not feel that their interest was that strong. Alex explained, "It [teaching] is something that I would want to experience for a short while, but I do not see myself being able to sustain that energy and excitement for it."

A few of the participants noted conflicting feelings about going into teaching and the length of time they would do it. They recognized that they would prefer to complete a teacher education program before teaching and then remain in the 
profession long enough to have the training and experience to be a good teacher, but their uncertainty made them lean towards simply trying it for a year or two rather than investing the time and money into a graduate program. As Katie said, "I have considered it...for short term. I am worried about the short term because it is a double-edged sword - I want to know whether I like it, but I also want to be good at it and I do not know whether I would be good at it in the short term. If I wanted to do it, I would want to be really well prepared."

Five of the ten participants considering teaching as a short-term option had applied to or were thinking about Teach for America (TFA) or other similar teaching fellow programs, while only three had applied to teacher education programs. TFA was seen as accommodating their desire to experience teaching for a few years, give back to a community, gain skills and experience, and then move on to something else. As Laura said, "TFA is a great option in the sense that I do not know what I want to do. So taking two or three years off from whatever I want to do would be a great way to give back and have time to figure it out. So, lax time." As her view illustrates, and the surveys corroborate, students do not seem to consider interest in teaching a prerequisite for interest in TFA. Students felt that TFA allows students to experience the public service aspect of teaching for a few years, without having to "sacrifice" anything in the long-term.

\section{Influences}

Participants referenced a number of different sources that contributed to their range of views on teaching and their perception of it as a sacrifice, including experience teaching, parents or relatives, peers, and classes related to education. The most frequently mentioned influence was the experience of teaching or tutoring, discussed by 15 students. The experiences that the students had in teaching, tutoring, or as camp counselors influenced their views of the reality of teaching and their desire to pursue it or not. Eight of the participants said that their time of tutoring or teaching gave them a new perspective on how school systems work, the large impact that teachers can have on their students, and the realities of schools in low-income areas, where most of them had worked.

The next most frequently mentioned influence was family, discussed by 12 of the interviewees. No one said that a family member encouraged them to go into teaching, and many said that they were actively discouraged from teaching, with parents highlighting what they perceived as negative aspects of the career. Only three students described at least one of their parents as supportive of whatever they chose to do. Eight of the participants said either that their parents had actually discouraged them from teaching or that, if they had never discussed teaching with their parents, they believed that their parents would not be happy about it. Students said that their parents' main concern was that teaching did not pay enough and that 
it was hard, often frustrating work. As Laura said, "I feel like if I were to say, "Dad, I am using my $\$ 150,000$ education to make $\$ 35,000$ a year," they would be a little disappointed in me." Whether or not their parents had actually expressed them, the participants felt that their parents had expectations that their daughter would have a high-paying job and that they would be letting them down if they did not.

Four of these students even had mothers or other close relatives who were or had been teachers, all of whom actively encouraged them to think about other careers. Jamie, whose mother has been a teacher for 30 years, said, "I have definitely seen the downside of being a teacher. She loves it...but she does not advise that path for me just because she knows what it is like." This student's perception of "what it is like" based on her mother's experience was that there was a lot of bureaucracy to navigate in a school district and that one could put in a lot of effort and passion into teaching but not see any effect of one's hard work. Jess had a cousin who had decided to do TFA before law school. His family's reaction had been that it was noble, but not prestigious enough to pursue for more than a year or two. Rachel had an aunt who had taught and saw from her aunt's experience that teaching was hard and that she never had enough resources to do as much as she wanted with her students. Anna, whose parents had discouraged her from teaching, had an aunt and an uncle who were both teachers and loved it. Their enjoyment of teaching and the fact that they were accepted in her family encouraged her to pursue teaching as an option despite her parents views. She had already applied to teacher education programs.

While parents were cited slightly less frequently as a source of information about teaching than past teachers and experiences, they seemed to be one of the most important and salient sources because of the weight that students gave to their views. Eva, who had decided to teach and had been interested in it since a young age, said "I considered other careers somewhat because I was discouraged from considering teaching." Students' perceptions of their parents views, correct or not, seem to have a significant impact on the careers they seriously consider. In the case of teaching, parents seem to reinforce perceptions of teaching as a noble, but ultimately not worthwhile, pursuit, either because of the relatively low salary or the amount of work required in the face of significant barriers.

Seven of the participants said that their peers had influenced their views of teaching. Four mentioned peers as negative influences, either because they had done TFA and had bad experiences or because they did not consider teaching to be a good option for a student from their university. This influenced both their own desire to teach as well as their view of whether or not teaching was a worthwhile career for a graduate of their university. Eva, who had already been discouraged from teaching by her parents, said "I have had conversations with my peers [and they] question why I am going into teaching because I would not be making 'enough' money. They definitely provide a way for me to see that other side of society- the side that thinks education is necessary but also does not think that [university's name] graduates should pursue teaching." Four students, however, also discussed 
peers as positive influences. These students had friends who were interested in education issues or teaching and shared that enthusiasm with them. Eva noted that she also knew "a lot of people who share my value about giving to the community regardless of salary." These peers provided a support for those considering teaching by sharing similar values and normalizing teaching as a career option for graduates of their university.

Only three students mentioned classes as sources of their views on teaching, possibly reflecting the lack of an undergraduate track in education at this university. Jamie and Lisa had concentrations within American Studies and Urban Studies that related to education and thus had taken education classes to fulfill their requirements. Most of these classes were focused on issues in urban education or the difficulties of striving for equity in education, which the students said had led them to be somewhat cynical about the possibilities for positive change in public education. Lindsay, who was hoping to work in education policy, had also taken some of these classes and been depressed about what she then saw as the "realities" of the American education system.

\section{IMPLICATIONS}

Most of the students interviewed and surveyed believed teaching to be a public service and, in fact, found that to be one of the most attractive aspects of the job. When it came to thinking about their own career decisions, however, the participants' perceptions of the negative aspects of teaching led them to consider it a sacrifice at the expense of the teacher. While large numbers of students at this university were interested in teaching, most did not see themselves going into, or staying in, the profession. Most were deterred by their perceptions of teaching's salary, status, difficulty, and the often negative opinions of others. The alarming picture this presents is that even students interested in teaching feel there are significantly more reasons not to go into teaching than to go into it. This may, in fact, help explain the great success TFA has had in recruiting college students - it resolves this sacrifice dilemma. Students are able to indulge their interest in teaching and desire to do a public service without sacrificing prestige, money for a graduate degree in teaching, or the chance for a more lucrative, high-status career afterwards. Having become a prestigious and very competitive program, TFA teachers are often seen as having more prestige than teachers who entered through other routes. Many students, then, see TFA not as a way to enter the teaching profession, but as a way to experience teaching, gain new skills, and then move on to a new career. Increasing the supply and improving the quality of career teachers will thus require figuring out why students perceive teaching to be a sacrifice and how to change that perception.

Given that high-achieving students have many reasons to choose careers other teaching, how can more of them be encouraged to explore the profession? While 
the public service aspect of teaching is certainly one of its main attractors, it needs to be more than a public service to attract and keep top candidates and must not be seen as a sacrifice. Considering these findings of what students are looking for in a career, what they see as attractive or unattractive about teaching, and the sources of their information and views, increasing the number of high-achieving students entering and staying in teaching is a large and important task that cannot be successfully undertaken by one institution alone. Proposals are made here for changes at four different institutional levels: society and government, universities, teacher education programs, and schools.

First and foremost, society must accept that the education of succeeding generations is a critical task for society and one that, in an increasingly technologically driven economy, will require greater competence and ability from teachers. In order to reverse the current decline in teacher aptitude, society as a whole is going to have to recognize the need to provide teaching salaries that are competitive with those provided by other learned professions, which will in turn help raise the status of teaching as a profession. This will not be an easy burden for society to bear; particularly as, for some initial period, society may believe that many current teachers do not perform at a level that deserves greater compensation.

Colleges and universities must find ways of emphasizing and letting students experience the attractors to and benefits of teaching through sources influential to them, including tutoring programs, peers, and classes. Methods for doing this could range from the creation of a pre-education group for students interested in the field, which would give them access to support from like-minded peers and to valuable information about the teaching profession, to the implementation of an undergraduate minor in education at universities without an undergraduate program in teaching. A new minor would allow students to receive academic credit and formal recognition for their studies in education and provide them with encouragement and assistance from peers as well as faculty members. Classes offered should not focus solely on problems in education, but also on its successes and possibilities for the future. Finally, incorporating information on teaching, learning, and lesson plan design into existing tutoring programs could help students use these experiences as a way to test out their interest in teaching and to begin honing their skills. As well as emphasizing the benefits of teaching, colleges and universities must address the perceived opportunity costs of entering teaching for this group of high-achieving students. The current restructuring of financial aid packages at many elite universities to replace loans with grants will likely alleviate some of students' concern about the comparatively low salary structure of the teaching profession and the added cost of earning a teaching credential.

Teacher education programs also have a significant role to play in attracting new high-achieving teaching candidates. Loan-forgiveness programs and needbased and merit-based scholarships would help encourage students to pursue their 
interest in teaching instead of choosing higher paying opportunities. Teacher education programs must also recruit and advertise more aggressively to compete with the far-reaching and well-entrenched pull of TFA as most of TFA's recruits do not become long-term teachers. Finally, schools and districts can help change the perception of the difficulties of teaching and the notion that it is a sacrifice for the teacher by providing positive working conditions and professional support for their teachers. While there are many barriers to changing students perceptions of teaching, it is such an essential task, which ultimately affects all of the society, that it must be undertaken by society and its institutions.

\section{REFERENCES}

Astin, A. (1993). What matters in college? Liberal Education, 79(4), 4-15.

Boyd, D., Lankford, H., Loeb, S., Rockoff, J., \& Wyckoff, J. (2007). The narrowing gap in New York City teacher qualifications and its implications for achievement in highpoverty schools. Working paper no. 10. Cambridge, MA: National Center for Longitudinal Data in Education Research.

Chandler, M. A. (2007). Schools pinched in hiring: Teacher shortage looms as law raises bar and boomer women retire. The Washington Post. Retrieved on April 30, 2008. from http://thewashingtonpost.com

Corcoran, S. P., Evans, W. N., \& Schwab, R. M. (2004). Women, the labor market, and the declining relative quality of teachers. Journal of Policy Analysis and Management, 23(3), 449.

Darling-Hammond, L. (1999). Teacher quality and student achievement: A review of state policy evidence. Center for the Study of Teaching and Policy. University of Washington.

Darling-Hammond, L. (2000). How teacher education matters. Journal of Teacher Education, 51(3), 166.

Dillon, S. (2007, August 27). With turnover high, schools fight for teachers. The New York Times. Retrieved April 30, 2008, from http://www.nytimes.com

Figlio, D. N. (1997). Teacher salaries and teacher quality. Economics Letters, 55, 267-271.

Flyer, F., \& Rosen, S. The new economics of teachers and education. (1997). Journal of Labor Economics, 15(1), 104-139.

Goldin, C. (2005). From the valley to the summit: A brief history of the quiet revolution that transformed women's work. Regional Review, 14(3), 5-12.

Grissmer, D., \& Kirby, S. J. (1997). Teacher turnover and teacher quality. Teachers College Record, 99, 45-56.

Hoxby, C. M., \& Leigh, A. (2004). Pulled away or pushed out? Explaining the decline of teacher aptitude in the United States. American Economic Review, Papers and Proceedings of the American Economic Association, 94(2), 236-240.

In search of good teachers [Editorial]. (2007, August 29). The New York Times. Retrieved April 30, 2008, from http://www.nytimes.com

Lankford, H., Loeb, S., \& Wyckoff, J. (2002). Teacher sorting and the plight of urban schools: A descriptive analysis. Educational Evaluation and Policy Analysis, 24(1), 37-62.

Lortie, D. C. (1975). Schoolteacher. Chicago, IL: The University of Chicago Press. 
Murnane, R. J. (1991) Who will Teach? Policies that Matter. Cambridge, MA: Harvard University Press.

Murnane, R. J., \& Olsen, R. J. (1989). The effects of salaries and opportunity costs on length of stay in teaching. The Journal of Human Resources, 15(1), 106-124.

Peshkin, A. (1991). In search of subjectivity - One's own [appendix]. The Color of Strangers, The Color of Friends. Chicago, IL: The University of Chicago Press.

Rice, J. K. (2003). Teacher Quality: Understanding the Effectiveness of Teacher Attributes. Washington, DC: Economic Policy Institute.

Rothstein, J., \& Rouse, C. E. (2007). Constrained after college: Student loans and early career occupational choices. NBER Working Paper No. w13177. Cambridge, MA: National Bureau of Economic Research.

Temin, P. (2002, April). Teacher quality and the future of America. NBER Working Paper No. 8898. Cambridge, MA: National Bureau of Economic Research.

\section{APPENDIX A: SURVEY}

\section{Perspectives on Teaching: Survey of Stanford Undergraduates Honors Thesis Project}

Study purpose: The purpose of this study is to explore undergraduates perspectives on teaching.

1. Year:

2. Major:

3. Sex: M F

4. Have you ever considered becoming a teacher after graduation? Circle one:

$\begin{array}{ccccc}\text { Never } & & \text { Somewhat } & & \text { Seriously } \\ 1 & 2 & 3 & 4 & 5\end{array}$

5. At which level have you or would you consider teaching? (Check all that apply)
Preschool
Secondary School
Would not consider teaching
Elementary school
University

6. What do you find attractive about teaching? (Check all that apply)
Working with people
Rendering a public service
Staying in an educational setting
Material benefits (money, status, job security)

\section{Work Schedule}

Working for social justice Interest in a specific subject

Not attracted to teaching

7. What programs have you considered?

Teach for America

Graduate Teacher Education

Program (certification)
Teaching Fellows, or other alternative program

Other, please specify:

None 
8. In comparison with teaching, what do you find more attractive about other professions you have considered?
Work type
Status
$\square$ Salary and benefits
Work schedule and conditions
Other, please specify:

For questions 9-13, rate your level of agreement or disagreement with the following statements:

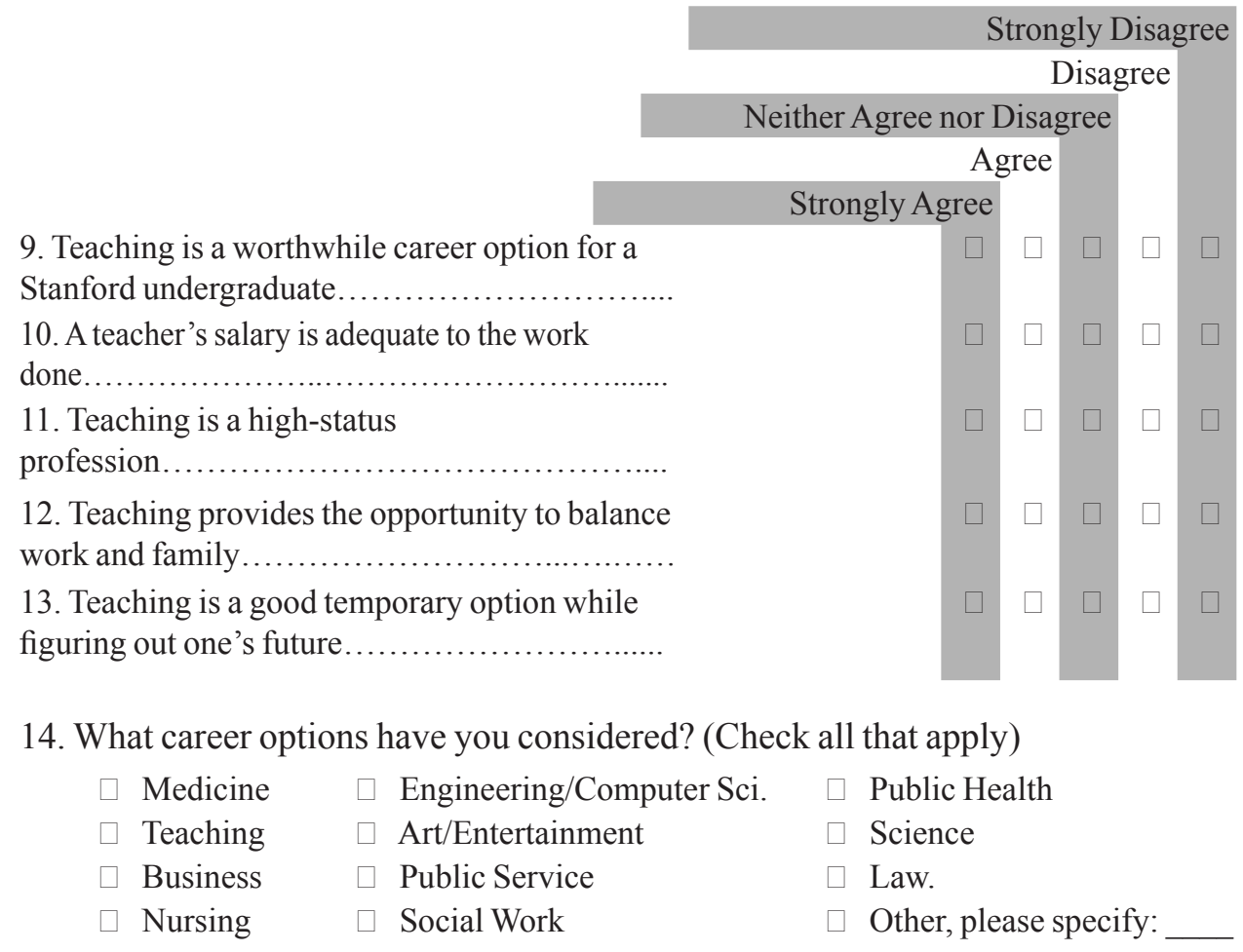

If you are interested in discussing your views more and being paid \$20 for an hour of time, list your email here: . Completion of this survey signifies consent. No identifying information will be gathered or used from this survey.

\section{APPENDIX B: INTERVIEW PROTOCOL}

1. What is your class year?

2. What are you studying here at Stanford?

3. Can you tell me a little bit about why you chose that area of study?

4. When considering career options, what do you feel to be the most important factors affecting your decision? 
5. What career options have you considered?

6. Have you ever considered teaching?

If yes:
a. At what level?
b. Long or short term?
c. What attracts/attracted you to teaching?

If no:

a. Why not?

7. From your perspective, how do the other options you have considered compared with teaching?

8. What is your perception of teaching as a career?

9. What do you think about the amount teachers are paid for the work they do?

10. How do you think teaching is viewed as a profession in our society?

11. Is it a worthwhile pursuit for a Stanford graduate?

12. What different sources have contributed to your perspectives on teaching and careers? 